\title{
Enzyme activity highlights the importance of the oxidative pentose phosphate pathway in lipid accumulation and growth of Phaeodactylum tricornutum under $\mathrm{CO}_{2}$ concentration
}

Songcui Wu ${ }^{1,2+}$, Aiyou Huang ${ }^{1 \dagger}$, Baoyu Zhang ${ }^{1}$, Li Huan ${ }^{1,2}$, Peipei Zhao ${ }^{1,2}$, Apeng Lin ${ }^{1}$ and Guangce Wang ${ }^{1 *}$

\begin{abstract}
Background: Rising $\mathrm{CO}_{2}$ concentration was reported to increase phytoplankton growth rate as well as lipid productivity. This has raised questions regarding the NADPH supply for high lipid synthesis as well as rapid growth of algal cells.

Results: In this study, growth, lipid content, photosynthetic performance, the activity, and expression of key enzymes in Calvin cycle and oxidative pentose phosphate pathway (OPPP) were analyzed in the marine diatom Phaeodacty/um tricornutum under three different $\mathrm{CO}_{2}$ concentrations (low $\mathrm{CO}_{2}\left(0.015 \%\right.$ ), mid $\mathrm{CO}_{2}$ (atmospheric, $0.035 \%$ ) and high $\mathrm{CO}_{2}$ $(0.15 \%)$ ). Both the growth rate and lipid content of $P$. tricornutum increased significantly under the high $\mathrm{CO}_{2}$ concentration. Enzyme activity and mRNA expression of three Calvin cycle-related enzymes (Rubisco, 3-phosphoglyceric phosphokinase (PGK), phosphoribulokinase (PRK)) were also increased under high $\mathrm{CO}_{2}$ cultivation, which suggested the enhancement of Calvin cycle activity. This may account for the observed rapid growth rate. In addition, high activity and mRNA expression of G6PDH and 6PGDH, which produce NADPH through OPPP, were observed in high $\mathrm{CO}_{2}$ cultured cells. These results indicate OPPP was enhanced and might play an important role in lipid synthesis under high $\mathrm{CO}_{2}$ concentration.
\end{abstract}

Conclusions: The oxidative pentose phosphate pathway may participate in the lipid accumulation in rapid-growth $P$. tricornutum cells in high $\mathrm{CO}_{2}$ concentration.

Keywords: $\mathrm{CO}_{2}$, Lipids, Enzyme activity, Oxidative pentose phosphate pathway, Phaeodactylum tricornutum

\section{Background}

As a result of increased industrialization and human activities, global carbon dioxide $\left(\mathrm{CO}_{2}\right)$ emission has increased dramatically and induces seawater acidification, which affects the growth and photosynthesis of marine phytoplankton [1]. Photosynthetic $\mathrm{CO}_{2}$ fixation by phytoplankton (e.g., eukaryotic microalga) mainly depends upon Calvin cycle, and ribulose-1, 5-bisphosphate carboxylase/ oxygenase (Rubisco) catalyzes the initial step of $\mathrm{CO}_{2}$ fixing. The response of photosynthesis, metabolite including the Calvin cycle enzymes (especially Rubisco), and growth to elevated $\mathrm{CO}_{2}$ have been well studied in higher

\footnotetext{
*Correspondence: gcwang@qdio.ac.cn

${ }^{\dagger}$ Equal contributors

'Key Laboratory of Experimental Marine Biology, Institute of Oceanology, Chinese Academy of Sciences, Nanhai Road 7, Qingdao 266071, China Full list of author information is available at the end of the article
}

plants. It was shown that short-term $\mathrm{CO}_{2}$ elevating generally accelerates carbon fixation and leads to an increase of Rubisco activity followed by an enhancement of growth in $\mathrm{C}_{3}$ plants [2-6]. Yet, in the long-term, the photosynthesis decreased with increasing $\mathrm{CO}_{2}$, which is typically accompanied by a decline in the amount and activity of Rubisco and other enzymes in the Calvin cycle and a decrease of growth rates. Compared to high plants, the impacts of elevated $\mathrm{CO}_{2}$ concentration on microalgae and their response to $\mathrm{CO}_{2}$ levels, especially Calvin cycle enzyme (including Rubisco) activity and amount, have been learned much less extent and attentions mainly paid to photosynthesis and algal growth. Only in the study of Euglena gracilis Z, Nakano et al. focused on Rubisco and found Rubisco activity was higher in high $\mathrm{CO}_{2}$ conditions [7]. Whereas, elevated $\mathrm{CO}_{2}$ concentration 
increased the efficiency of photosynthetic carbon fixation and growth of phytoplankton was gradually known as general phenomenon [8, 9]. Kim et al. [10] reported that the growth of Skeletonema costatum enhanced at higher concentrations of $\mathrm{CO}_{2}$. Tortell et al. [11] also found that rising $\mathrm{CO}_{2}$ can enhance Chaetoceros spp. growth. In addition, various studies have shown that rising $\mathrm{CO}_{2}$ concentration increases lipid productivity as well as phytoplankton growth rate, such as in Phaeodactylum tricornutum [12], Nannochloropsis oculata [13], and Chlorella vulgaris [14], high levels of $\mathrm{CO}_{2}$ concentration enhanced both biomass production and lipid content, thus shedding light on the potential for biodiesel production from microalgae. To select microalgae for obtaining a higher lipid productivity, even higher concentrations of $\mathrm{CO}_{2}\left(10 \% \mathrm{CO}_{2}\right.$ and flue gas) were used to cultivate Botryococcus braunii and Scenedesmus sp. [15]. At present, about 60 species of microalgae have been well domesticated with high concentration of $\mathrm{CO}_{2}$ for producing large biomass and achieving high biofuel yields [16]. However, most previous studies have only focused on microalgal growth rate, lipid content, and tolerance to high levels of $\mathrm{CO}_{2}$ [17-20]. Little effort has been directed toward the analysis of the mechanism involved in lipid accumulation in microalgae and their simultaneous rapid growth rate.

Microalgal lipids, as a source of biofuel, are usually derived from long-chain fatty acids, which require NADPH for synthesis $[21,22]$. For example, to produce an 18carbon fatty acid, $16 \mathrm{NADPH}$ molecules are required as electron donors. Therefore, enhanced lipid accumulation will surely increase metabolic demand in microalgae for $\mathrm{NADPH}$. Microalgae have been demonstrated to grow rapidly in high $\mathrm{CO}_{2}$ concentrations. This suggests that quantity of NADPH, which is supplied by the light reaction, is required for photosynthetic carbon fixation which supplies substrates and energy for the synthesis of major constituents (proteins, nucleic acids, and carbohydrates) essential for algal growth. For effective $\mathrm{CO}_{2}$ fixation, ATP and NADPH produced by photosynthetic light reactions must be maintained at a molar ratio of $3: 2$ [23]. Once a large number of NADPH molecules are consumed, the ratio will be disrupted leading to a reduction in carbon fixation activity. An important question therefore remains about how NADPH is supplied for high fatty acid synthesis as well as rapid growth of algal cells cultured under high $\mathrm{CO}_{2}$ concentration. It is more likely that another pathway may contribute to providing this reductant.

In the present study, we evaluated the lipid content in the diatom $P$. tricornutum which was cultivated in three different $\mathrm{CO}_{2}$ conditions $(0.015 \%$, atmospheric, and $0.15 \%)$. Furthermore, we measured the activity of seven key enzymes and mRNA expression in P. tricornutum to explore the mechanism of rapid growth and the simultaneous increase in lipid accumulation in high- $\mathrm{CO}_{2}$ cultured algal cells. Our research showed that the pentose phosphate pathway may be incorporated in maintaining the NADPH supply under high $\mathrm{CO}_{2}$ concentrations.

\section{Results}

Algal growth, $\mathrm{pH}$ changes, and photosynthetic performance under low, mid, and high $\mathrm{CO}_{2}$ concentrations

When grown under low, mid, and high $\mathrm{CO}_{2}$ concentrations, the growth rate of $P$. tricornutum showed significant differences among the groups. The highest growth rate occurred under high $\mathrm{CO}_{2}$ concentration and was 0.20 at the beginning of treatment and 0.70 on the seventh day at the optical density (OD) of $730 \mathrm{~nm}$, followed by mid $\mathrm{CO}_{2}$ concentration, and was 0.20 at the beginning of treatment and 0.41 on the seventh day at $\mathrm{OD}_{730 \mathrm{~nm}}$. No significant growth was observed in the low- $\mathrm{CO}_{2}$ cultured alga (Fig. 1a). This indicated that when nutrients were sufficient, the carbon source performs as the limiting factor which affected algal growth.

Figure $1 \mathrm{~b}$ shows that the medium $\mathrm{pH}$ had a significant increase on day 1 under both mid- $\mathrm{CO}_{2}$ (from 8.83 to 9.41) and low- $\mathrm{CO}_{2}$ (from 8.83 to 9.45) conditions, and from day 2 to 7 , the $\mathrm{pH}$ of mid- $\mathrm{CO}_{2}$ and low- $\mathrm{CO}_{2}$ cultures gradually increased, whereas the $\mathrm{pH}$ of algal culture bubbled with high level of $\mathrm{CO}_{2}$ strongly decreased on day 1 (from 8.83 to 7.07 ) and then gradually increased from 7.07 to 8.32. Faster growth and greater carbon fixation were observed in high- $\mathrm{CO}_{2}$ cultured $P$. tricornutum under the low $\mathrm{pH}$ and high $\mathrm{CO}_{2}$ condition. The consumption of $\mathrm{NO}_{3}^{-}$during algal rapid growth may cause the increase of culture $\mathrm{pH}$ from day 2 to 7 under high $\mathrm{CO}_{2}$ concentration, and this increase of $\mathrm{pH}$ might correlate with algal growth rate and carbon fixation efficiency. Compared with high- $\mathrm{CO}_{2}$ culture, both mid- and low- $\mathrm{CO}_{2}$ cultures had an increase of culture $\mathrm{pH}$ values associated with a relative slow growth after bubbled with mid and low levels of $\mathrm{CO}_{2}$ from day 2 to 7 .

As shown in Fig. 1c, d, both high- $\mathrm{CO}_{2}$ and mid- $\mathrm{CO}_{2}$ cells obtained high values of maximal photosynthesis system II (PSII) quantum yield $\left(F_{\mathrm{v}} / F_{\mathrm{m}}\right)$ and effective PSII quantum yield (YII) during cultivation, and they all firstly represented a significant increase of $F_{\mathrm{v}} / F_{\mathrm{m}}$ and $\mathrm{Y}$ (II) values and then gradually decreased. The high- $\mathrm{CO}_{2}$ cells consistently had the highest $F_{\mathrm{v}} / F_{\mathrm{m}}$ and $\mathrm{Y}$ (II) values, followed by mid carbon cultured alga. Whereas, low $\mathrm{CO}_{2}$ cultivated alga had the lowest $F_{\mathrm{v}} / F_{\mathrm{m}}$ and Y (II) values, which obviously decreased during cultivation. This suggested that the response to $\mathrm{CO}_{2}$ concentration in algal cells was also reflected in the changes in algal photosynthesis. 

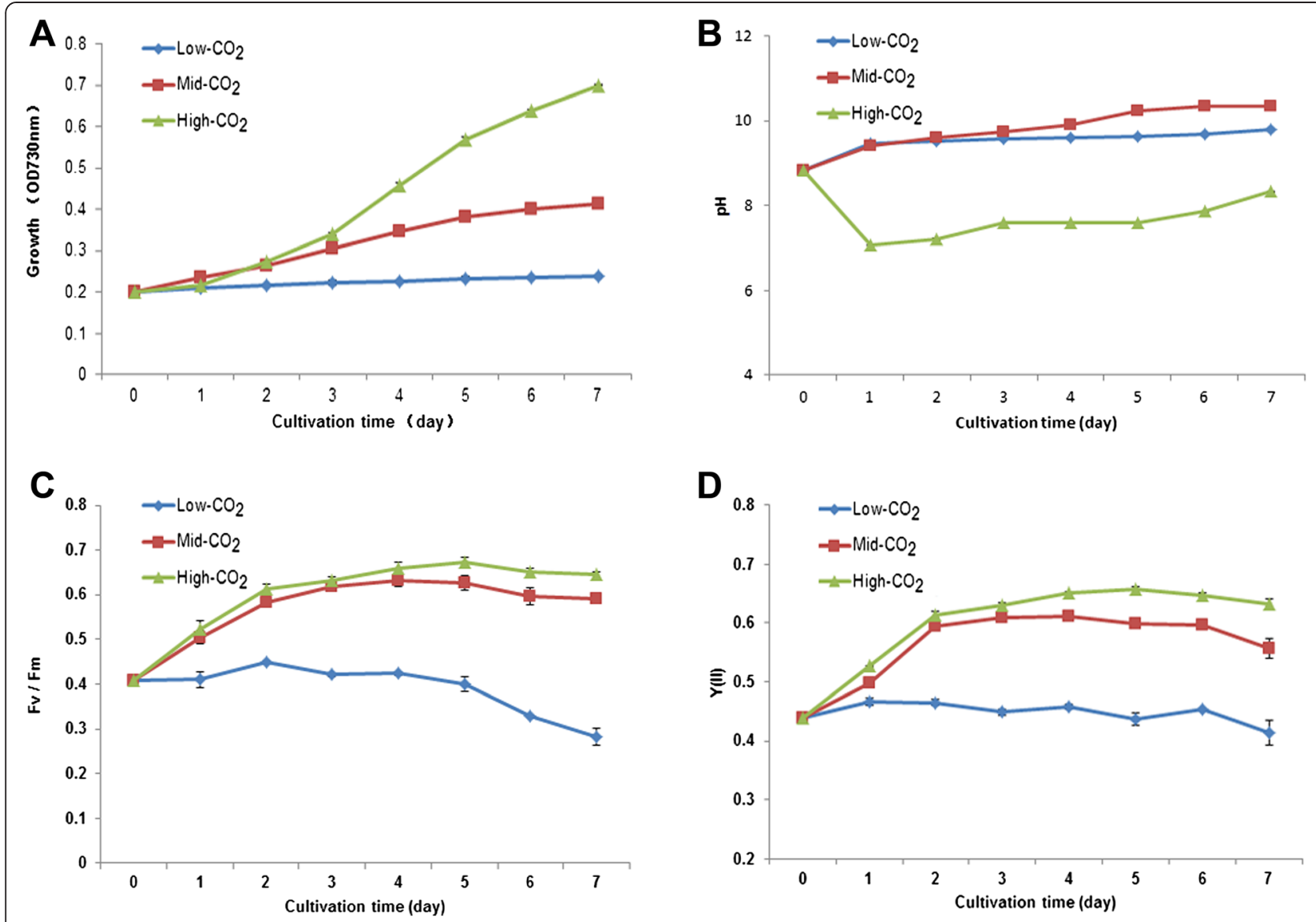

Fig. 1 Effects of $\mathrm{CO}_{2}$ concentration on growth, medium $\mathrm{pH}$, and photosynthetic performance of $P$. tricornutum. a Growth curve of $P$. tricornutum; b $\mathrm{pH}$ changes of all of the cultures; $\mathbf{c}$ The maximum quantum yield of PSII $\left(F_{\mathrm{v}} / F_{\mathrm{m}}\right)$ in $P$. tricornutum; $\mathbf{d}$ The effective PSII quantum yield (YII) in $P$. tricornutum. Data are expressed as a mean \pm SD $(n=3)$

Lipid, fatty acid composition, total water-soluble proteins, chlorophyll $a+c$ content and RNA concentration in algal cells measured under different $\mathrm{CO}_{2}$ concentrations

As described above, the concentration of $\mathrm{CO}_{2}$ had significant effects on $P$. tricornutum growth. To investigate the influence of $\mathrm{CO}_{2}$ concentrations on intracellular substances, we determined the lipid, total water-soluble proteins, and chlorophyll $a+c$ content in $P$. tricornutum treated with different $\mathrm{CO}_{2}$ concentrations. Table 1 shows that when grown under the high $\mathrm{CO}_{2}$ condition, $P$. tricornutum had the highest lipid content $(53.71 \pm 2.41 \%$, $w / w, \%$ of dry cell weight (DCW)), followed by mid $\mathrm{CO}_{2}$ cultivated cells of $35.87 \pm 1.72 \%$, and low $\mathrm{CO}_{2}$ cultured P. tricornutum had the lowest lipid content of $33.13 \pm$ $1.21 \%$. As shown in Table 2, in low- and mid- $\mathrm{CO}_{2}$ cultured cells, $7.41 \%$ (\% of DCW) and $8.72 \%$ (\% of DCW) are longer-chain fatty acids $(\geq 20 \mathrm{C})$, respectively. Whereas, in high- $\mathrm{CO}_{2}$ cultured cells, the longer-chain fatty acids ( $\geq 20 \mathrm{C}$ ) account in $16.41 \%$ of dry cell weight. It was represented that a significant increase of longer-chain fatty acids content in high- $\mathrm{CO}_{2}$ cultured cells, compared to low- and mid- $\mathrm{CO}_{2}$ cultured cells. These results suggested

Table 1 Dry weight and intracellular substances contents in three different $\mathrm{CO}_{2}$ concentrations cultivated P. tricornutum cells. Intracellular substances involved total water-soluble protein, lipids, chlorophyll a $+\mathrm{c}$ and RNA concentration. Data are expressed as a mean $\pm \mathrm{SD}(n=3)$

\begin{tabular}{lccr}
\hline $\mathrm{CO}_{2}$ concentration & Low- $\mathrm{CO}_{2}(0.015 \%)$ & $\mathrm{Mid}_{-} \mathrm{CO}_{2}(0.035 \%)$ & $\mathrm{High}-\mathrm{CO}_{2}(0.150 \%)$ \\
\hline Culture dry weight $\left(\mathrm{g} \mathrm{L}^{-1}\right)$ & 0.083 & 0.109 & 0.245 \\
Lipid content $(w / W$, \% of DCW) & $33.13 \pm 1.2$ & $35.87 \pm 1.7$ & $53.71 \pm 2.4$ \\
Chlorophyll $a+c$ concentration $\left(\mathrm{mmol} \mathrm{g}{ }^{-1} \mathrm{FW}\right)$ & $2.52 \pm 0.084$ & $3.73 \pm 0.030$ & $3.28 \pm 0.084$ \\
RNA concentration $\left(\mu \mathrm{g} \mathrm{g}^{-1} \mathrm{FW}\right)$ & $378.10 \pm 10.42$ & $715.40 \pm 15.45$ & $562.39 \pm 33.51$ \\
Total water-soluble protein production $\left(\mathrm{mg} \mathrm{g}^{-1} \mathrm{FW}\right)$ & $7.63 \pm 0.03$ & $12.76 \pm 0.04$ & $16.29 \pm 0.02$ \\
\hline
\end{tabular}


Table 2 Fatty acid compositions of $P$. tricornutum under different $\mathrm{CO}_{2}$ concentration cultivation (w/w, \% of DCW)

\begin{tabular}{|c|c|c|c|}
\hline Fatty acids & Low- $\mathrm{CO}_{2}(\%)$ & Mid- $\mathrm{CO}_{2}(\%)$ & High- $\mathrm{CO}_{2}(\%)$ \\
\hline $14: 0$ & 3.52 & 3.82 & 5.10 \\
\hline $16: 0$ & 4.65 & 6.03 & 8.67 \\
\hline $16: 1 \omega 7$ & 6.61 & 8.28 & 12.25 \\
\hline $16: 2 \omega 4$ & 1.29 & 1.62 & 1.95 \\
\hline $16: 3 \omega 4$ & 2.01 & 2.57 & 3.20 \\
\hline $16: 4 \omega 1$ & 0.29 & 0.46 & 0.43 \\
\hline $18: 0$ & 3.85 & 3.49 & 4.87 \\
\hline $18: 2 \omega 6$ & 0.99 & 0.80 & 0.83 \\
\hline $20: 5 \omega 3$ & 5.17 & 6.80 & 11.58 \\
\hline $22: 0$ & 0.27 & 0.16 & 0.78 \\
\hline $22: 4 \omega 7$ & 0.44 & 0.22 & 0.64 \\
\hline $22: 5 \omega 3$ & 0.26 & 0.34 & 0.79 \\
\hline $24: 0$ & 1.27 & 1.21 & 2.62 \\
\hline Total 14 18C & 25.72 & 27.06 & 37.30 \\
\hline Total 20 24C & 7.41 & 8.72 & 16.41 \\
\hline
\end{tabular}

that the high- $\mathrm{CO}_{2}$ cultured cells need much more cytosolic-generated reductant for lipids or longer-chain fatty acid synthesis.

Table 1 exhibits the maximum water-soluble protein yield $16.29 \pm 0.02 \mathrm{mg} \mathrm{g}^{-1} \mathrm{FW}$ in $P$. tricornutum also occurred in the high $\mathrm{CO}_{2}$ cultivated cells, while the mid$\mathrm{CO}_{2}$, and low- $\mathrm{CO}_{2}$ cells had relatively lower soluble protein contents of $12.76 \pm 0.04$ and $7.63 \pm 0.03 \mathrm{mg} \mathrm{g}^{-1}$ fresh weight $(\mathrm{FW})$, respectively. Although high- $\mathrm{CO}_{2} P$. tricornutum cells had high lipid and water-soluble protein contents, the concentration of chlorophyll $a+c$ and RNA were lower than those in mid $\mathrm{CO}_{2}$ cultured cells (Table 1). Low- $\mathrm{CO}_{2}$ cultured cells had the lowest yield of intracellular substances, which may have been due to the limiting of carbon source.

\section{Assays of the change in enzyme activities}

P. tricornutum maintained in high $\mathrm{CO}_{2}$ concentration had the highest growth rate among the three experimental groups (Fig. 1). To investigate the mechanism underlying the different growth rates due to $\mathrm{CO}_{2}$ concentration, the activities of key enzymes in the Calvin cycle, including Rubisco, 3-phosphoglyceric phosphokinase (PGK), and phosphoribulokinase (PRK) were analyzed. As shown in Fig. 2, these enzymes showed maximum activity in P. tricornutum under the high $\mathrm{CO}_{2}$ concentration, followed by mid- $\mathrm{CO}_{2}$ cultured cells, which were slightly higher than low- $\mathrm{CO}_{2}$ cultured cells, but no significant difference was observed in the activity of PRK between mid- $\mathrm{CO}_{2}$ and low- $\mathrm{CO}_{2}$ cultured cells $(P>0.05)$. These results suggest that the activity of the Calvin cycle was enhanced under high $\mathrm{CO}_{2}$ cultivation, which was well matched with the high growth rate

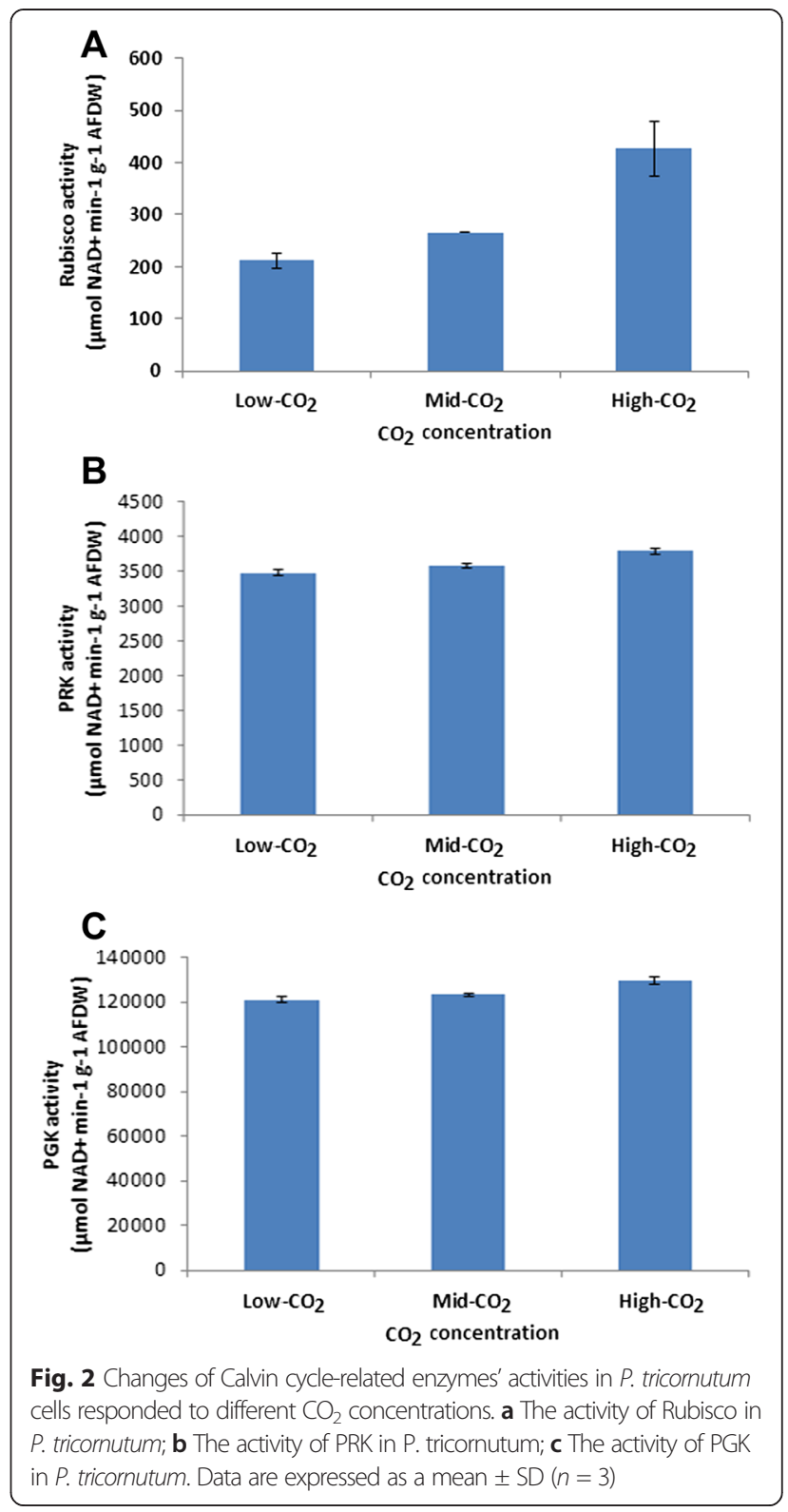

and photosynthetic performance of $P$. tricornutum in the high- $\mathrm{CO}_{2}$ concentration.

In addition, alga cells grown under the high $\mathrm{CO}_{2}$ concentration had a maximum yield of lipids (Table 1 ). This prompted us to investigate probable pathways which supplied NADPH for lipid synthesis, as NADPH is essential for elongation of fatty acids. To the best of our knowledge, in the photosynthetic cells of plants, de novo biosynthesis of 16-carbon and 18-carbon fatty acids occurs in the chloroplast, where NADPH is produced via the light reactions of photosynthesis. The 16-carbon fatty acids (e.g., palmitate) are elongated to yield the 20carbon and even longer-chain fatty acids in the cytosol, so these elongation steps are the only ones that require cytosolic-generated reductant [24]. 
The oxidative pentose phosphate pathway (OPPP) is the major resource of NADPH in the cytoplasm. To better understand the carbon flux and reductant source for lipid synthesis in $P$. tricornutum cells under three different $\mathrm{CO}_{2}$ concentrations, the activities of G6PDH and 6PGDH, two key enzymes in the OPPP, were evaluated. Figure 3 shows the activities of G6PDH and 6PGDH, and these results showed that G6PDH and 6PGDH activities were highest under high- $\mathrm{CO}_{2}$ cultivation, while algal cells maintained in mid- and low- $\mathrm{CO}_{2}$ showed lower and lowest activity, respectively. These findings indicate that the activity of the OPPP was enhanced in cells under high- $\mathrm{CO}_{2}$ cultivation and may have supplied NADPH for lengthening the fatty acids chain.

As the OPPP is not the sole producer of NADPH, to verify whether the other sources for NADPH could contribute to cytosolic fatty acids elongation, two tricarboxylic acid (TCA) cycle enzymes activity were detected. Figure 4 shows that no significant differences were observed in the activity of $\mathrm{MDH}$ of three different $\mathrm{CO}_{2}$ concentration cultured $P$. tricornutum cells. Whereas, the activity of $\alpha$-ketoglutarate dehydrogenase ( $\alpha-\mathrm{KGDH})$ was peaked in high- $\mathrm{CO}_{2}$ cultivated $P$. tricornutum cells, followed by mid- $-\mathrm{CO}_{2}$ cells, and the low- $\mathrm{CO}_{2}$ cultivated
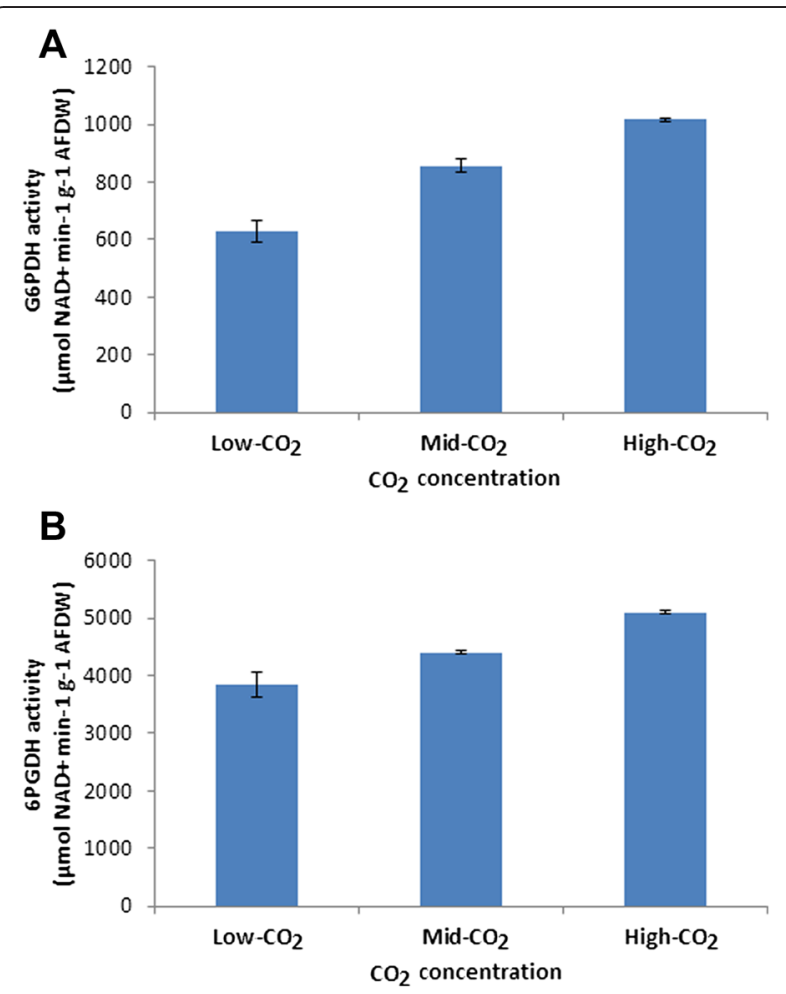

Fig. $3 \mathrm{G} 6 \mathrm{PDH}$ and 6PGDH activities in P. tricornutum maintained with three different $\mathrm{CO}_{2}$ concentrations. Both G6PDH and $6 \mathrm{PGDH}$ had relatively high activities in high- $\mathrm{CO}_{2}$ cultivated $P$. tricornutum cells. a The activity of G6PDH in P. tricornutum; $\mathbf{b}$ The activity of $6 \mathrm{PGDH}$ in $P$. tricornutum. Data are expressed as a mean $\pm \mathrm{SD}(n=3)$

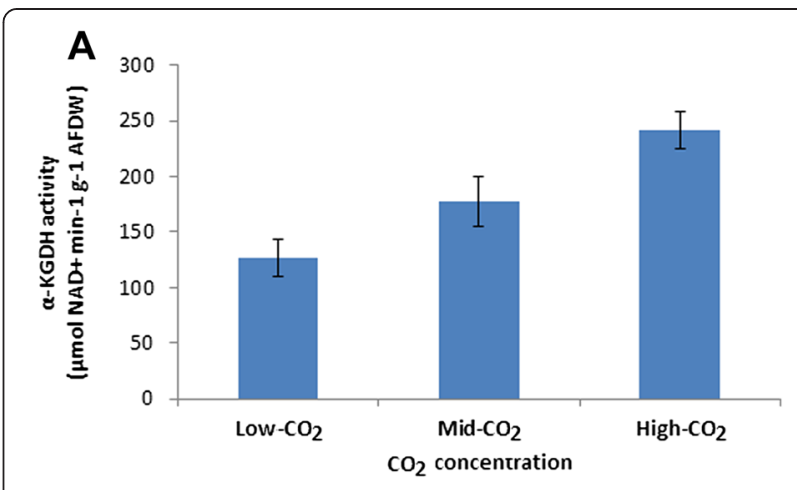

B

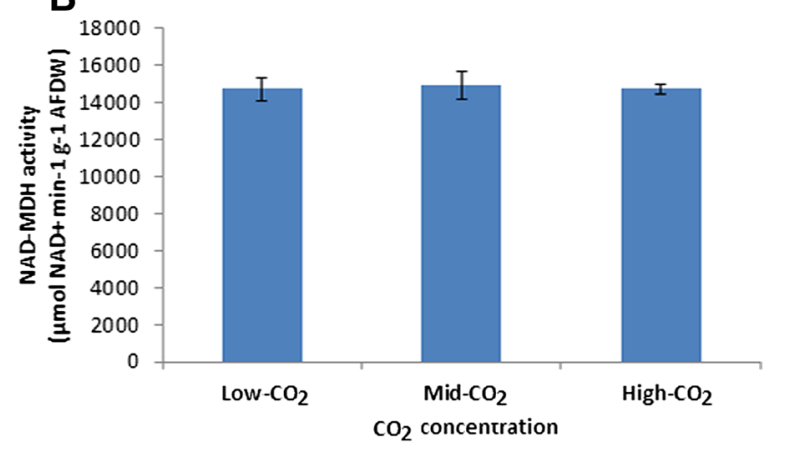

Fig. 4 The activities of two TCA cycle enzymes in P. tricornutum cultured with different $\mathrm{CO}_{2}$ concentrations. a The activity of a-KGDH; b The activity of MDH. Data are expressed as a mean $\pm \mathrm{SD}(n=3)$

cells had the lowest $\alpha-\mathrm{KGDH}$ activity. As $\alpha-\mathrm{KGDH}$ is the rate-determining enzyme of the TCA cycle [25], the activity of $\alpha-\mathrm{KGDH}$ was positively correlated with TCA cycle activity. High $\alpha-K G D H$ activity indicated a general enhancement of the TCA cycle under high $\mathrm{CO}_{2}$ concentration.

Analysis of enzyme mRNA expression measured by qPCR The results of real-time PCR showed that under high $\mathrm{CO}_{2}$ concentration, $P$. tricornutum had the highest relative expression level of Rubisco, PRK, PGK, G6PDH, and 6PGDH among the three treatments (Figs. 5 and 6). The expressions of Rubisco, PGK, and G6PDH in mid$\mathrm{CO}_{2}$ cultivated $P$. tricornutum cells were higher than those of the low- $\mathrm{CO}_{2}$ cultured cells, but the expression of PRK and 6PGDH in mid - $\mathrm{CO}_{2}$ cultivated P. tricornutum was not significantly different to that found in low$\mathrm{CO}_{2}$ cultured cells $(P>0.05)$ The mRNA expression level of these enzymes was consistent with the results of enzyme activity, which indicated that $P$. tricornutum under high $\mathrm{CO}_{2}$ cultivation not only had high enzyme activities but also high mRNA content. Higher enzyme activities and mRNA expression levels of Rubisco, PGK, and PRK suggested that, in Calvin cycle, the $\mathrm{CO}_{2}$ fixation, carbon reduction, and ribulose-1,5-bisphosphate $(\mathrm{RuBP})$ regeneration were enhanced; in other words, the 


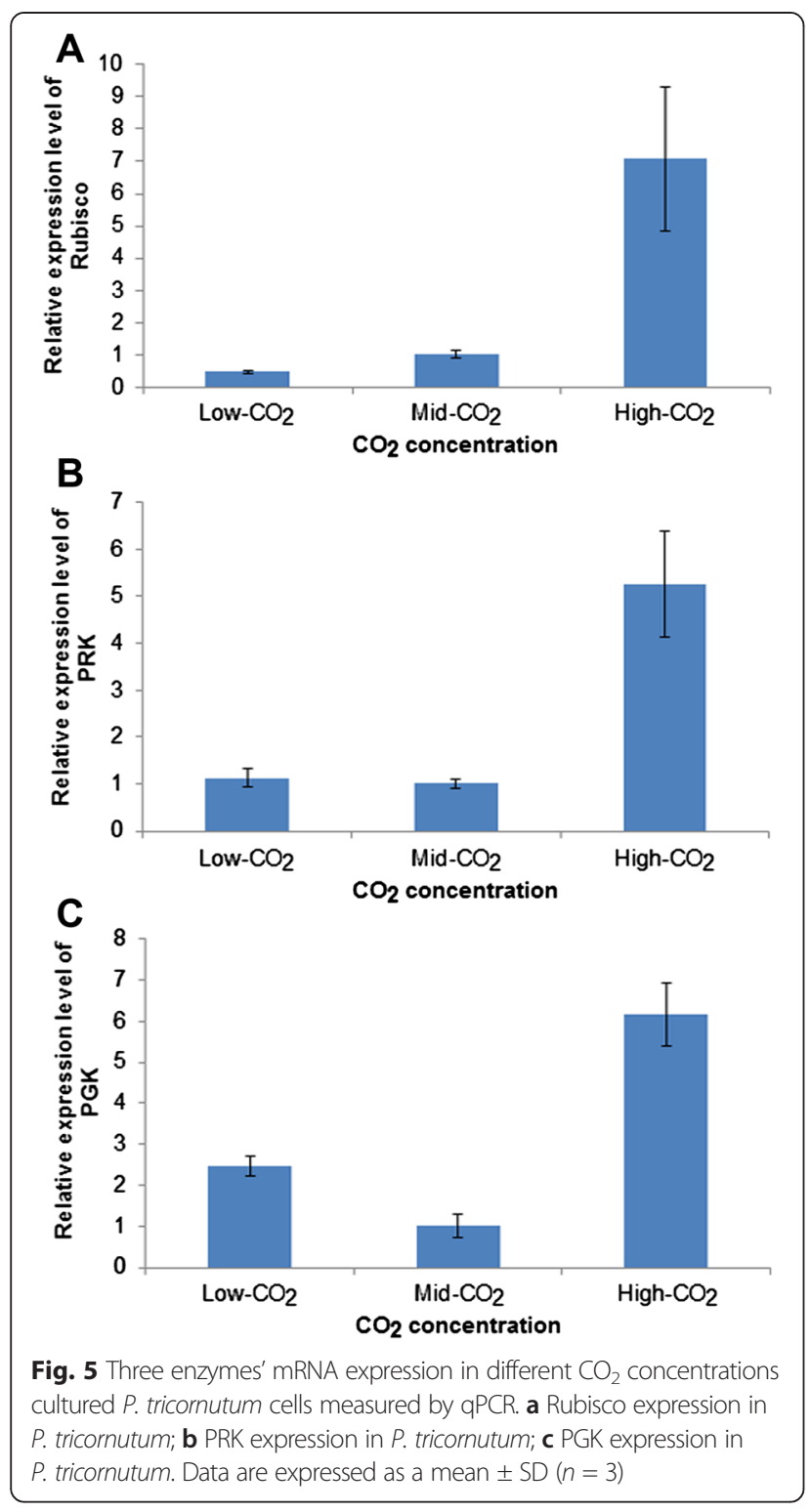

carbon fixation efficiency of Calvin cycle elevated and the production of carbon skeleton for biosynthesis increased. These might positively correlate with rapid growth of $P$. tricornutum under high $\mathrm{CO}_{2}$ concentration.

\section{Discussion}

As described in Fig. 1, P. tricornutum can tolerate relatively high levels of $\mathrm{CO}_{2}$ and has a rapid growth rate when cultivated in high $\mathrm{CO}_{2}$ concentration, which was consistent with the finding that rising $\mathrm{CO}_{2}$ concentration increased phytoplankton growth rate $[1,8,9,12,26]$. Moreover, Rubisco activity and mRNA expression were increased (Figs. 2 and 5) under high $\mathrm{CO}_{2}$ concentration. As the rate-limiting and key regulatory enzyme of the Calvin cycle, the level of Rubisco monitors the carbon flux through this pathway [27]. In addition to high Rubisco activity, the activities of
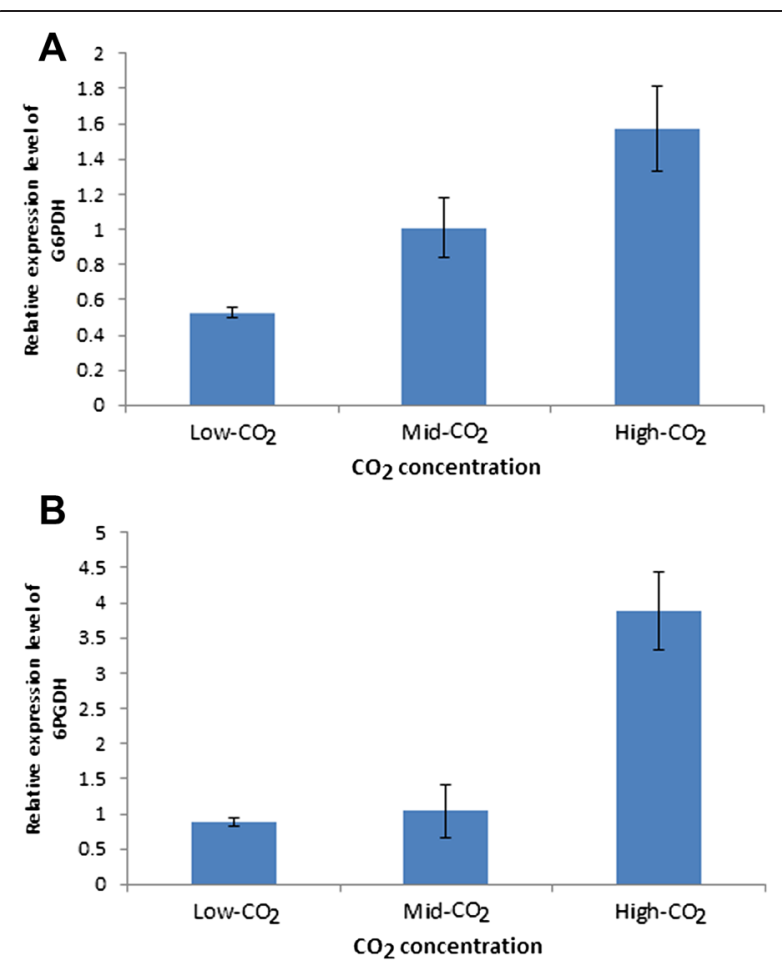

Fig. 6 The expressions of G6PDH and 6PGDH in P. tricornutum cultured with different $\mathrm{CO}_{2}$ concentration. a The relative expression level of $\mathrm{G} 6 \mathrm{PDH} ; \mathbf{b}$ The relative expression level of $6 \mathrm{PGDH}$. Data are expressed as a mean $\pm \mathrm{SD}(n=3)$

PRK and PGK were high in high $\mathrm{CO}_{2}$ concentration cultured cells and significantly higher than Rubisco activity. Rubisco acts as a $\mathrm{CO}_{2}$ receptor and takes part in the carbon fixation stage of the Calvin cycle, and PGK participates in the reduction stage of the Calvin cycle, whereas PRK is incorporated in the regeneration phase in the Calvin cycle; high activities of Rubisco, PGK, and PRK in high $\mathrm{CO}_{2}$ cultured cells indicated that the Calvin cycle activity was enhanced and was operating effectively in algal cells under high $\mathrm{CO}_{2}$ cultivation. This may account for the rapid growth rate observed. However, when $P$. tricornutum was grown under low $\mathrm{CO}_{2}$ concentration, the activities of the Calvin cycle-related enzymes were weaker, which suggested that substrates and energy required for algal growth were deficient. This might be the major reason why no significant growth under the low $\mathrm{CO}_{2}$ concentration of algal cells was observed. These results indicated elevated $\mathrm{CO}_{2}$ concentration provided plenty of carbon resource for photosynthetic carbon fixation and then induced an enhancement of algal photosynthetic carbon fixation and growth rate which were consistent with numerous previous studies that higher levels of $\mathrm{CO}_{2}$ support higher growth rates.

As expected, a significant increase in lipid content was also found in the high $\mathrm{CO}_{2}$ cultivated rapid-growth $P$. tricornutum cells. As we know, microalgal lipid production typically begins at the onset of nitrogen depletion as the 
$\mathrm{C} / \mathrm{N}$ ratio (carbon to nitrogen ratio) in algal cells increased, which lead to most of the fixed carbon divert into nitrogen deficient compounds such as lipids [28]. In this research, $P$. tricornutum were maintained in nitrogen repletion cultures, which might not trigger lipid accumulation. Yet we observed 1.5-fold increase of lipid content in high- $\mathrm{CO}_{2}$ cultured cells, compared to mid- $\mathrm{CO}_{2}$ cultured cells. We thought that maybe because of a higher $\mathrm{C} / \mathrm{N}$ ratio in algal cells that caused by high $\mathrm{CO}_{2}$ concentration. This is supported by the conclusion that the elemental stoichiometry (carbon to nitrogen ratio) was raised under high $\mathrm{CO}_{2}$ conditions in both nitrogen limited and nitrogen replete conditions in $P$. tricornutum according to $\mathrm{Li}$ et al. [29].

Lipids, especially triacylglycerol (TAG), primarily serve as a storage form of carbon and energy in algal cells [30], which require numerous NADPH molecules for biosynthesis in the cytoplasm. During rapid growth of algal cells, ATP and NADPH generated by the light reaction are mainly supplied for the maintenance of algal growth. Therefore, under high $\mathrm{CO}_{2}$ cultivation, the key problem in the rapid growth of algal cells is how the additional NADPH required for lipid synthesis comes from. NADPH can be primarily generated from the OPPP or TCA cycle. The first two steps of the OPPP, catalyzed by G6PDH and $6 \mathrm{PGDH}$ respectively, are the major source of NADPH. As shown in Fig. 6, with a high level of $\mathrm{CO}_{2}$ concentration, enhanced activity and mRNA expression of G6PDH and 6PGDH were observed, except for increased lipid accumulation, which indicated that OPPP activity was enhanced. In a study of Chlorella, Xiong et al. [31] found that NADPH supplied through OPPP increased under nitrogen limited condition when lipid synthesis increased, and they speculated that NADPH from the mitochondrial TCA cycle was difficult to be trapped for lipid metabolism in the cytoplasm. The enhancement of TCA cycle might contribute to two possibilities: (i) to provide ATP for lipid synthesis; (ii) to produce quantity of intermediates (e.g., malic acid) to offer substrate or carbon skeleton for fatty acid synthesis [32]. Thus, G6PDH together with 6PGDH that are of great importance in the synthesis of the reductant NADPH through the OPPP [33], may play an important role in elongation of fatty acids under high $\mathrm{CO}_{2}$ concentration.

\section{Conclusions}

In this study, growth, lipid content, photosynthetic performance, the activity, and expression of key enzymes in Calvin cycle and OPPP were analyzed in the marine diatom $P$. tricornutum under three different $\mathrm{CO}_{2}$ concentrations. Both the growth rate and lipid content of $P$. tricornutum increased significantly under the high $\mathrm{CO}_{2}$ concentration. Enzyme activity and mRNA expression of three Calvin cycle-related enzymes (Rubisco, PGK, PRK) were also increased under high $\mathrm{CO}_{2}$ cultivation, which suggested the enhancement of the Calvin cycle activity. This may account for the observed rapid growth rate. In addition, high activity and mRNA expression of G6PDH and 6PGDH, which produce NADPH through OPPP, were observed in high $\mathrm{CO}_{2}$ cultured cells. These results indicate OPPP was enhanced and might play an important role in elongation of fatty acids or lipid synthesis under high $\mathrm{CO}_{2}$ concentration.

\section{Methods}

\section{Alga strain cultivation}

P. tricornutum was screened from the East China Sea and confirmed unialgal as previously described by Wu et al. [34]. The alga strain was cultivated in sterilized carbon source deprived artificial seawater enriched with $\mathrm{f} / 2$-Si medium [35] and grown at $20 \pm 1{ }^{\circ} \mathrm{C}$ under a constant light intensity of $100 \mu \mathrm{mol} \mathrm{m} \mathrm{m}^{-2} \mathrm{~s}^{-1}$ with a 14:10 h light-dark (L/D) cycle.

\section{$\mathrm{CO}_{2}$ treatment}

The alga culture was maintained with aeration and cultivated in 2-L flasks containing $1.5-\mathrm{L}$ medium. Three different $\mathrm{CO}_{2}$ concentrations in the bubbling aeration system were tested: low $\mathrm{CO}_{2}(0.015 \%)$, mid $\mathrm{CO}_{2}$ (atmospheric, $0.035 \%$ ), and high $\mathrm{CO}_{2}(0.15 \%)$. The handheld indoor air quality testing detector Telaire $7001 \mathrm{CO}_{2}$ Monitor (USA), which can be able to display $\mathrm{CO}_{2}$ readings in less than $30 \mathrm{~s}$, was used to measure $\mathrm{CO}_{2}$ concentration in this study. Each treatment included three replicates. The $\mathrm{pH}$ of algal culture bubbled with different $\mathrm{CO}_{2}$ concentration was daily measured using a Switzerland Mettler Toledo Delta $320 \mathrm{pH}$ meter.

\section{Growth and photosynthetic determination}

Algal growth was measured daily by cell number and the OD value at the optical wavelength for $P$. tricornutum (730 nm) using a spectrophotometer (UV-1800). A hemocytometer was used to count algal cells.

To investigate the photosynthetic performance of $P$. tricornutum in response to $\mathrm{CO}_{2}$ concentration, the chlorophyll fluorescence of PSII was measured by a Dual-PAM-100 fluorometer (Heinz Walz, Effeltrich, Germany) which was conducted with a PC using the WinControl software (Heinz Walz). Two parameters, the maximum quantum yield of PSII $\left(F_{\mathrm{v}} / F_{\mathrm{m}}\right)$ and the effective PSII quantum yield (YII), were evaluated using the pulse-amplitude modulated method as described by Lin et al. [36] with some modifications. To ensure the consistency of cell density for PAM fluorescence measurement, the growing algal samples were adjusted to 0.6 at $\mathrm{OD}_{730 \mathrm{~nm}}$ before detected. The minimum fluorescence $\left(F_{0}\right)$ and maximum fluorescence $\left(F_{\mathrm{m}}\right)$ were determined after the samples were incubated in darkness for $5 \mathrm{~min}$. 
Variable fluorescence $\left(F_{\mathrm{v}}\right)$ was calculated according to formula $F_{\mathrm{v}}=F_{\mathrm{m}}-F_{0}$. The maximal PSII quantum yield was calculated as $F_{\mathrm{v}} / F_{\mathrm{m}}$. The effective quantum yield of PSII (Y (II)) was calculated as $\left(\vec{F}_{\mathrm{m}}^{\prime}-F\right) / \vec{F}_{\mathrm{m}}^{\prime}$ where $\vec{F}_{\mathrm{m}}^{\prime}$ was the maximal fluorescence detected under photosynthetic active radiation (PAR) of $58 \mu \mathrm{mol} \mathrm{m}{ }^{-2} \mathrm{~s}^{-1}$ and $F$ is the real-time fluorescence yield under illumination.

\section{Lipid analysis}

Algal cultures were harvested after 7-day cultivation by centrifugation at $5000 \mathrm{~g}$, and the algal cells were quickly frozen in liquid nitrogen. A freeze dryer was used to dry the frozen algal cells. Lipids were extracted from $50 \mathrm{mg}$ dryness algal powder using a modified chloroformmethanol system as described by Bligh and Dyer [37]. Crude samples were dried with $\mathrm{N}_{2}$ flow until a constant weight was obtained. Gravimetric means, a conventional lipid quantification method, was used for total lipid analysis. The fatty acid compositions of different $\mathrm{CO}_{2}$ concentration cultivated P. tricornutum were determined by gas chromatography [38].

\section{Enzyme assays}

Harvested algal cells were washed twice with $0.01 \mathrm{M}$ PBS buffer ( $\mathrm{pH}$ 7.4) and were ground into fine powder using a pre-chilled mortar and pestle with liquid $\mathrm{N}_{2}$. Crude enzyme extracts were prepared from the algal powder in three times the volume of ice-cold extraction buffer. Enzyme activities were determined spectrophotometrically using a UV-1800 spectrophotometer by measuring at $340 \mathrm{~nm}$ in total volumes of $0.4 \mathrm{~mL}$ and in triplicate. The change in absorbance was recorded for 5 min. Results were expressed as $\mu$ mol NAD (P) $\mathrm{H}$ oxidation or NAD $(\mathrm{P})^{+}$reduction $\min ^{-1} \mathrm{~g}^{-1}$ AFDW, as we had standardized the correlation between fresh weight and ash-free dry weight of different $\mathrm{CO}_{2}$ cultured P. tricornutum. The compositions of the extract and assay medium for the respective enzymes are detailed below. All chemicals and enzymes used for enzyme assays were purchased from Sigma-Aldrich (Sigma-Aldrich Co. LLC., USA).

Rubisco (ribulose-1, 5-bisphosphate carboxylase/oxygenase), which controls the initial step in photosynthetic carbon fixation via the Calvin cycle, is one of the most abundant proteins in both higher plants and algae [39]. The carboxylase activity of Rubisco relative to photosynthetic rates has been reported in many previous studies of macroalgae and microalgae [27]. Rubisco (EC 4.1.1.39) activity was measured using a modification of the basic procedure according to Gerard and Driscoll [27]. $300 \mu \mathrm{L}$ of chilled extraction buffer ( $40 \mathrm{mM}$ Tris- $\mathrm{HC} 1,0.25 \mathrm{mM}$ EDTA, $10 \mathrm{mM} \mathrm{MgCl}_{2}, 5 \mathrm{mM}$ glutathione, at $\mathrm{pH}$ 7.6) was added per 100-mg fresh algal powder. The mixture was stirred for $2 \mathrm{~min}$ to homogeneity, and centrifuged at $13,000 \mathrm{~g}$ for $10 \mathrm{~min}$. The supernatants were incubated on ice for further enzyme assays. The reaction mixture contained $0.1 \mathrm{M}$ Tris- $\mathrm{HCl}\left(\mathrm{pH}\right.$ 7.8), $0.2 \mathrm{mM} \mathrm{NaHCO}{ }_{3}, 12$ $\mathrm{mM} \mathrm{MgCl}_{2}, 5 \mathrm{mM} \mathrm{NADH}, 50 \mathrm{mM}$ ATP, $50 \mathrm{mM}$ phosphocreatine, 160 units per milliliter of creatine phosphokinase (EC 2.7.3.2), and PGK (EC 2.7.2.3), and $25 \mathrm{mM}$ $\mathrm{RuBP}$ was added to initiate the reaction.

For measurement of PRK (EC 2.7.1.19) and PGK activities in crude extracts, the method described by Rao and Terry [40] was used. Frozen fresh algal cells were extracted in three times the volume of extraction buffer (100 mM Hepes- $\mathrm{NaOH}\left(\mathrm{pH}\right.$ 8.0), $10 \mathrm{mM} \mathrm{MgCl}_{2}, 0.4$ mM EDTA, $1 \%$ polyvinypyrrolidone, $100 \mathrm{mM} \mathrm{Na}-$ ascorbate, $0.1 \%$ BSA at $0-4{ }^{\circ} \mathrm{C}$ ) and then stirred for 2 min with a vortex at a maximum speed. Crude homogenates were then centrifuged at $13,000 \mathrm{~g}$ for $10 \mathrm{~min}$. The supernatants were prepared for further assays. For the assay of PRK, pre-chilled $30 \mathrm{mM}$ Hepes- $\mathrm{NaOH}$ (pH 8.0), containing $10 \mathrm{mM} \mathrm{MgCl}, 5 \mathrm{mM}$ DL-Dithiothreitol (DTT), $2 \mathrm{mM}$ ATP, $2 \mathrm{mM}$ phosphoenolpyruvic acid, 0.4 $\mathrm{mM}$ ribose-5-phosphate, $0.3 \mathrm{mM} \mathrm{NADH}, 2$ units per $\mathrm{mL}$ of ribose-5-phosphate isomerase (EC 5.3.1.6), lactic dehydrogenase (EC 1.1.1.27), and pyruvate kinase (EC 2.7.1.40) was used as the assay media; the reaction was initiated by adding the algal extract. The activity of PGK (EC 2.7.2.3) was assayed in $30 \mathrm{mM}$ Hepes- $\mathrm{KOH}(\mathrm{pH}$ 7.8), $5 \mathrm{mM} \mathrm{MgCl}, 1 \mathrm{mM} \mathrm{NaF}, 1 \mathrm{mM} \mathrm{KH_{2 }} \mathrm{PO}_{4}, 5 \mathrm{mM}$ DTT, $2 \mathrm{mM}$ ATP, $4 \mathrm{mM}$ phosphoglycerate, $0.3 \mathrm{mM}$ $\mathrm{NADH}$, and 4 units per $\mathrm{mL}$ of NAD-glyceraldehyde-3phosphate dehydrogenase (EC 1.2.1.12) and triose phosphate isomerase (EC 5.3.1.1); the reaction was initiated by adding ATP.

The oxidation pentose phosphate pathway is the major resource of cytosolic-generated $\mathrm{NADPH}$, which is catalyzed by G6PDH and 6PGDH. G6PDH, the rate-limiting and key regulatory enzyme of the OPPP, controls the flow of carbon through this pathway and produces reductant to meet the cellular needs for reductive biosynthesis. To determine the activities of G6PDH (EC 1.1.1.49) and 6PGDH (EC 1.1.1.44), the method described by Fahrendorf et al. [41] was used with some modifications. Algal cells prepared as described above were extracted in $50 \mathrm{mM}$ Tris$\mathrm{HC} 1 \mathrm{pH}$ 8.0, $300 \mathrm{mM} \mathrm{NaC1}, 0.1 \mathrm{mM}$ benzamidine, and $0.1 \mathrm{mM}$ phenylmethylsulfonyl fluoride (PMSF). G6PDH activity was measured in a continuous assay at $30{ }^{\circ} \mathrm{C}$, including $0.1 \mathrm{M}$ Tris-HC1 pH 8.0, 0.4 $\mathrm{mM} \mathrm{NADP}^{+}$, and 3 $\mathrm{mM}$ glucose-6-phosphate. 6PGDH activity was measured at $30^{\circ} \mathrm{C}$ in $0.1 \mathrm{M}$ Hepes $\mathrm{pH} 7.5,0.4 \mathrm{mM} \mathrm{NADP}{ }^{+}$, and 3 $\mathrm{mM}$ 6-phosphogluconate. Reactions were started by the addition of algal extracts. Reduction of $\mathrm{NADP}^{+}$at $340 \mathrm{~nm}$ was used to monitor G6PDH and 6PGDH activities.

TCA cycle is another major resource of NADPH, via isocitrate dehydrogenase. To verify whether this process contributes reductant to fatty acid elongation, the activity of two TCA cycle enzymes, $\alpha-\mathrm{KGDH}$ and $\mathrm{MDH}$ was 
measured following the method as described by Peng $\mathrm{L}$ and Shimizu K [42]. Algal cells were extracted in $100 \mathrm{mM}$ Tris- $\mathrm{HCl}$ (pH 7.0) containing $20 \mathrm{mM} \mathrm{KCl,} 5 \mathrm{mM} \mathrm{MnSO} 4$, $2 \mathrm{mM}$ DTT, and $0.1 \mathrm{mM}$ EDTA. The assay conditions were as follows: $\alpha-\mathrm{KGDH} 0.2 \mathrm{M}$ phosphate buffer $(\mathrm{pH}$ 7.2), $1 \mathrm{mM}$ CoASH, $0.1 \mathrm{M}$ cysteine- $\mathrm{HCl}$ (pH 7.2), $10 \mathrm{mM}$ $\mathrm{NAD}+(\mathrm{pH}$ 7.2), $3 \mathrm{mM}$ a-ketoglutarate. Malate dehydrogenase, $0.1 \mathrm{M}$ Tris- $\mathrm{HCl}$ ( $\mathrm{pH} 8.8$ ), $0.1 \mathrm{mM}$ sodium malate, $10 \mathrm{mM} \mathrm{NAD+}$, and reactions were started by the addition of algal extracts.

\section{Real-time PCR analysis}

Total RNA was extracted from frozen algal powder using the Plant RNA kit (OMEGA, Norcross, USA) following the manufacturer's instructions which included the first step of genomic DNA digestion. The concentrations of RNA extracts were measured using a NanoDrop 1000 Spectrophotometer (Thermo, Wilmington, Delaware, USA).

For single strand cDNA synthesis, the PrimeScript RT regent Kit with gDNA Eraser (TaKaRa Biotech Co., Dalian, China) was used to perform the reverse transcription reaction according to the user's manual. In this protocol, further genomic DNA removal was performed to purify the RNA extracts. All tests were performed on ice. PCR was performed to confirm the absence of genomic DNA contamination.

Real-time PCR was performed with the cDNA template from the reverse transcription reaction and five pairs of specific primers (Table 3). Primers were designed based on the alignment of the deduced amino-acid sequences, which were obtained from the National Center for Biotechnology Information (NCBI) web site (http://www.ncbi.nlm.nih.gov/ blast), using the Primer Premier 5.0 software. Levels of specific mRNA transcripts were quantified by the Bio-Rad iQ5 Multicolor Real-Time PCR Reaction system (Bio-Rad, Hercules, CA, USA). The real-time PCR amplifications were performed with the reagents from the Fast Essential DNA Green Master (Roche, Germany). The cycling parameters for real-time PCR were $95{ }^{\circ} \mathrm{C}$ for $10 \mathrm{~min}$ (denaturation), followed by 40 cycles at $94{ }^{\circ} \mathrm{C}$ for $10 \mathrm{~s}$ (denaturation), $58{ }^{\circ} \mathrm{C}$ for $20 \mathrm{~s}$ (primer annealing), and (c) $72{ }^{\circ} \mathrm{C}$ for $10 \mathrm{~s}$ (elongation). To ensure only the single specific DNA fragment was amplified, melting curve analyses were performed on all PCR products. Triplicate qPCRs were performed for each sample. Data derived from the PCR program were analyzed with the Bio-Rad optical system software.

\section{Chlorophyll estimations}

For P. tricornutum, the chlorophyll $a$ and $c 1+c 2$ content was estimated by a $90 \%$ acetone extraction system. Fifty-milligram fresh algal powder ground from frozen algal cells in liquid $\mathrm{N}_{2}$ was added in $5 \mathrm{~mL} 90 \%$ acetone and thereafter read the fluorescence emission of the centrifuged extracts at 664 and $630 \mathrm{~nm}$ which were obtained as described by Jeffrey and Humphrey [43].

\section{Total water-soluble proteins preparations}

P. tricornutum water-soluble proteins were prepared using the method according to Wang et al. [44] with some modifications. Algal water-soluble proteins were extracted in fivefold volume of pre-chilled extract buffer, containing $50 \mathrm{mM}$ Tris- $\mathrm{HCl}$ buffer (pH 8.0), 3 mMDTT, $5 \mathrm{mM} \mathrm{MgCl}_{2}, 10 \%$ glycerol, $0.5 \%$ polyvinylpyrrolidone (PVP), $5 \mathrm{mM} \mathrm{Na}_{2}$-EDTA, $1 \mathrm{mM}$ PMSF, $5 \mathrm{mM}$ benzimidin, $5 \mathrm{mM}$ Acoproicand, $1 \%(v / v)$ plant protease inhibitor cocktail (Sigma). Crude extracts were centrifuged at

Table 3 List of primers used in the real-time PCR analysis

\begin{tabular}{|c|c|c|c|}
\hline Primers & Sequence $\left(5^{\prime}-3^{\prime}\right)$ & Annealing temperature $\left({ }^{\circ} \mathrm{C}\right)$ & Amplicon size (bp) \\
\hline \multirow[t]{2}{*}{ RPS (ribosomal protein small subunit 30S) } & Sense: CGAAGTCAACCAGGAAACCAA & 56 & 166 \\
\hline & Antisense: GTGCAAGAGACCGGACATACC & & \\
\hline \multirow[t]{2}{*}{ TBP (TATA box binding protein) } & Sense: ACCGGAGTCAAGAGCACACAC & 56 & 175 \\
\hline & Antisense: CGGAATGCGCGTATACCAGT & & \\
\hline \multirow[t]{2}{*}{ Rubisco (rbc S) } & Sense: ACTCTGCTGGTGCTGTGCG & 56 & 214 \\
\hline & Antisense: TGGGATTGGCGTCGTTCTT & & \\
\hline \multirow[t]{2}{*}{ PRK } & Sense: GAAGTTTGCTGTCTITGCCTCT & 56 & 139 \\
\hline & Antisense: GATGGGTGTCTGTCCCTCCT & & \\
\hline \multirow[t]{2}{*}{ PGK } & Sense: TGGTGGTGGCGACTCTGT & 56 & 156 \\
\hline & Antisense: TACGCATTCCCGGCTTAC & & \\
\hline \multirow[t]{2}{*}{ G6PDH } & Sense: GCGAGAAATGGCACAAGG & 56 & 180 \\
\hline & Antisense: GTTCATCGCAGTCGGGAGA & & \\
\hline \multirow[t]{2}{*}{$6 \mathrm{PGDH}$} & Sense: GTTCACCGTTGCCGTTG & 56 & 143 \\
\hline & Antisense: CGACTTTCCGAGGCTTGCTG & & \\
\hline
\end{tabular}


$15,000 \mathrm{~g}$ for $30 \mathrm{~min}$ at $4{ }^{\circ} \mathrm{C}$, and the supernatants were used for proteins determination. The Coomassie Brilliant Blue G-250 assay was used for protein quantitation in the study [45].

\section{Statistical analysis}

All data are expressed as the mean \pm standard deviation (SD) of three independent experiments. All statistical analyses were conducted using SPSS, and $t$ test was used to identify data of any significance within the treatments at $P$ value $\leq 0.05$.

\section{Abbreviations}

OPPP: Oxidative pentose phosphate pathway; Rubisco: Ribulose-1, 5-bisphosphate carboxylase oxygenase; PGK: 3-phosphoglyceric phosphokinase; PRK: Phosphoribulokinase; G6PDH: Glucose-6-phosphate dehydrogenase; 6PGDH: 6-phosphogluconate dehydrogenase; RuBP: Ribulose-1,5-bisphosphate; PSII: Photosynthesis system II; DTT: DL-dithiothreitol; FW: Fresh weight; DCW: Dry cell weight; AFDW: Ash-free dry weight; TCA cycle: Tricarboxylic acid cycle; a-KGDH: a-ketoglutarate dehydrogenase; MDH: Malate dehydrogenase.

\section{Competing interests}

The authors declare that they have no competing interests.

\section{Authors' contributions}

$\mathrm{SW}, \mathrm{AH}$, and GW designed the experiments. SW and AH carried out the cultivation and analysis of lipid contents, enzyme activity, and mRNA expressions of $P$. tricornutum. BZ, LH, and PZ participated in the design of the primer used in the study. AL participated in the analysis of the photosynthetic performance of $P$. tricornutum. SW and GW drafted the manuscript. GW and AH revised the manuscript. GW conceived of the study. All authors read and approved the final manuscript.

\section{Acknowledgements}

This work was supported by International Science \& Technology Cooperation Program of China (ISTCP, 2015DFG32160), Ministry of Science and Technology of the PRC fundamental research work (NO. 2012FY112900-01), the National Natural Science Foundation of China (41406169), the Science and Technology Strategic Pilot of the Chinese Academy of Sciences (XDA05030401), and Tianjin Natural Science foundation (12JCZDJC22200).

\section{Author details}

'Key Laboratory of Experimental Marine Biology, Institute of Oceanology, Chinese Academy of Sciences, Nanhai Road 7, Qingdao 266071, China. ${ }^{2}$ College of Earth Sciences, University of Chinese Academy of Science, Beijing 100049, China

\section{Received: 26 June 2014 Accepted: 20 May 2015}

Published online: 28 May 2015

\section{References}

1. Wu Y, Gao K, Riebesell U. $\mathrm{CO}_{2}$-induced seawater acidification affects physiological performance of the marine diatom Phaeodactylum tricornutum. Biogeosciences. 2010;7:2915-23.

2. Gunderson CA, Wullschleger SD. Photosynthetic acclimation in trees to rising atmospheric $\mathrm{CO}_{2}$-a broader perspective. Photosynthesis Res. 1994;39:369-88.

3. Faria T, Wilkins D, Besford RT, Vaz M, Pereira JS, Chaves MM. Growth at elevated $\mathrm{CO}_{2}$ leads to down-regulation of photosynthesis and altered response to high temperature in Quercus suber L. seedlings. J Exp Bot. 1996:47:1755-61.

4. Cheng SH, Moore BD, Seemann JR. Effects of short- and long-term elevated $\mathrm{CO}_{2}$ on the expression of ribulose-1,5-bisphosphate carboxylase/oxygenase genes and carbohydrate accumulation in leaves of Arabidopsis thaliana (L.) Heynh. Plant Physiol. 1998;116:715-23.

5. Stitt M, Krapp A. The interaction between elevated carbon dioxide and nitrogen nutrition: the physiological and molecular background. Plant Cell Environ. 1999;22:583-621.
6. Bloom AJ, Smart DR, Nguyen DT, Searles PS. Nitrogen assimilation and growth of wheat under elevated carbon dioxide. Proc Natl Acad Sci U S A. 2002;99:1730-5.

7. Nakano Y, Miyatake K, Okuno H, Hamazaki K, Takenaka S, Honami N, et al. Growth of photosynthetic algae euglena in high $\mathrm{CO}_{2}$ conditions and its photosynthetic characteristics. Acta Horticult (Wageningen). 1996:440:49-54.

8. Riebesell U, Wolfgladrow DA, Smetacek V. Carbon-dioxide limitation of marine phytoplankton growth rates. Nature. 1993;361:249-51.

9. Hein $\mathrm{M}$, SandJensen $\mathrm{K} . \mathrm{CO}_{2}$ increases oceanic primary production. Nature. 1997;388:526-7.

10. Kim JM, Lee K, Shin K, Kang JH, Lee HW, Kim M, et al. The effect of seawater $\mathrm{CO}_{2}$ concentration on growth of a natural phytoplankton assemblage in a controlled mesocosm experiment. Limnol Oceanogr. 2006:51:1629-36

11. Tortell PD, Payne CD, Li YY, Trimborn S, Rost B, Smith WO, et al. $\mathrm{CO}_{2}$ sensitivity of southern ocean phytoplankton. Geophys Res Lett. 2008;35.

12. Yongmanitchai W, Ward OP. Growth of and omega-3-fatty-acid production by Phaeodactylum tricornutum under different culture conditions. Appl Environ Microbiol. 1991;57:419-25.

13. Chiu S-Y, Kao C-Y, Tsai M-T, Ong S-C, Chen C-H, Lin C-S. Lipid accumulation and $\mathrm{CO}_{2}$ utilization of Nannochloropsis oculata in response to $\mathrm{CO}_{2}$ aeration. Bioresour Technol. 2009;100:833-8.

14. Tsuzuki M, Ohnuma E, Sato N, Takaku T, Kawaguchi A. Effects of $\mathrm{CO}_{2}$ concentration during growth on fatty-acid composition in microalgae. Plant Physiol. 1990;93:851-6.

15. Yoo C, Jun SY, Lee JY, Ahn CY, Oh HM. Selection of microalgae for lipid production under high levels carbon dioxide. Bioresour Technol. 2010;101:S71-4.

16. Chisti Y. Biodiesel from microalgae. Biotechnol Adv. 2007;25:294-306.

17. Matsuda $Y$, Hara T, Colman B. Regulation of the induction of bicarbonate uptake by dissolved $\mathrm{CO}_{2}$ in the marine diatom. Phaeodactylum tricornutum Plant Cell Environ. 2001;24:611-20.

18. Hyun $B$, Jang $P G$, Lee WJ, Shin $K$. Effects of increased $\mathrm{CO}_{2}$ and temperature on the growth of four diatom species (Chaetoceros debilis, Chaetoceros didymus, Skeletonema costatum and Thalassiosira nordenskioeldii) in laboratory experiments. J Environ Sci Int. 2014;23:1003-12.

19. Schippers $\mathrm{P}$, Lurling $\mathrm{M}$, Scheffer $\mathrm{M}$. Increase of atmospheric $\mathrm{CO}_{2}$ promotes phytoplankton productivity. Ecol Lett. 2004;7:446-51.

20. Bermúdez M Jr (2010) Effect of $\mathrm{CO}_{2}$ on elemental composition and fatty acids of diatoms and concomitant effects on copepods. Master thesis. Christian-Albrechts-Universität zu Kiel, Faculty of Mathematics and Natural Sciences; 2010

21. Guschina IA, Harwood JL. Lipids and lipid metabolism in eukaryotic algae. Prog Lipid Res. 2006;45:160-86.

22. Harwood JL, Guschina IA. The versatility of algae and their lipid metabolism. Biochimie. 2009:91:679-84

23. Allen JF. Photosynthesis of ATP - electrons, proton pumps, rotors, and poise. Cell. 2002:110:273-6.

24. Leninger A, Nelson DL, Cox MM. Principles of biochemistry. New York: Worth Publishers: 1993

25. Li M, Ho PY, Yao SJ, Shimizu K. Effect of Ipda gene knockout on the metabolism in Escherichia coli based on enzyme activities, intracellular metabolite concentrations and metabolic flux analysis by ${ }^{13} \mathrm{C}$-labeling experiments. J Biotechnol. 2006;122:254-66.

26. Araujo SD, Garcia VMT. Growth and biochemical composition of the diatom Chaetoceros cf. wighamii brightwell under different temperature, salinity and carbon dioxide levels. I. Protein, carbohydrates and lipids. Aquaculture. 2005;246:405-12

27. Gerard VA, Driscoll T. A spectrophotometric assay for rubisco activity application to the kelp Laminaria saccharina and implications for radiometric assays. J Phycol. 1996:32:880-4.

28. Cescut J, Fillaudeau L, Molina-Jouve C, Uribelarrea J-L. Carbon accumulation in Rhodotorula glutinis induced by nitrogen limitation. Biotechnol Biofuels. 2014;7:164.

29. Li W, Gao KS, Beardall J. Interactive effects of ocean acidification and nitrogen-limitation on the diatom Phaeodactylum tricornutum. Plos One. 2012;7.

30. Hu Q, Sommerfeld M, Jarvis E, Ghirardi M, Posewitz M, Seibert M, et al. Microalgal triacylglycerols as feedstocks for biofuel production: perspectives and advances. Plant J. 2008:54:621-39. 
31. Xiong $W$, Liu LX, Wu C, Yang C, Wu QY. ${ }^{13} \mathrm{C}$-tracer and gas chromatography-mass spectrometry analyses reveal metabolic flux distribution in the oleaginous microalga Chlorella protothecoides. Plant Physiol. 2010;154:1001-11.

32. Recht L, Toepfer N, Batushansky A, Sikron N, Gibon Y, Fait A, et al. Metabolite profiling and integrative modeling reveal metabolic constraints for carbon partitioning under nitrogen starvation in the green algae Haematococcus pluvialis. J Biol Chem. 2014;289:30387-403.

33. Kletzien RF, Harris PKW, Foellmi LA. Glucose-6-phosphate-dehydrogenase-a housekeeping enzyme subject to tissue-specific regulation by hormones, nutrients, and oxidant stress. FASEB J. 1994;8:174-81.

34. Wu S, Zhang B, Huang A, Huan L, He L, Lin A, et al. Detection of intracellular neutral lipid content in the marine microalgae Prorocentrum micans and Phaeodactylum tricornutum using Nile red and BODIPY 505/515. J Appl Phycol. 2014;26:1659-68.

35. Guillard RR, Ryther JH. Studies of marine planktonic diatoms.1. Cyclotella nana Hustedt, and Detonula confervacea (Cleve) Gran. Can J Microbiol. 1962;8:229-39

36. Lin AP, Wang GC, Yang F, Pan GH. Photosynthetic parameters of sexually different parts of Porphyra katadai var. hemiphylla (Bangiales, Rhodophyta) during dehydration and re-hydration. Planta. 2009;229:803-10.

37. Bligh E, Dyer WJ. A rapid method of total lipid extraction and purification. Can J Biochem Physiol. 1959;37:911-7.

38. Li W-q, Li Q, Liao Q-b, Chen Q-h. Effect of temperature on fatty acid composition of four species of marine microalgae. J Oceanogr Taiwan Strai. 2003;22:9-13.

39. Wang C, Fan XL, Wang GC, Niu JF, Zhou BC. Differential expression of Rubisco in sporophytes and gametophytes of some marine macroalgae. Plos One. 2011;6.

40. Rao IM, Terry N. Leaf phosphate status, photosynthesis, and carbon partitioning in sugar-beet. I. Changes in growth, gas-exchange, and calvin cycle enzymes. Plant Physiol. 1989;90:814-9.

41. Fahrendorf T, Ni WT, Shorrosh BS, Dixon RA. Stress responses in alfalfa (Medicago sativa L.). XIX. Transcriptional activation of oxidative pentosephosphate pathway genes at the onset of the isoflavonoid phytoalexin response. Plant Mol Biol. 1995;28:885-900

42. Peng L, Shimizu K. Global metabolic regulation analysis for Escherichia coli K12 based on protein expression by 2-dimensional electrophoresis and enzyme activity measurement. Appl Microbiol Biotechnol. 2003;61:163-78.

43. Jeffrey SW, Humphrey GF. New spectrophotometric equations for determining chlorophylls a, b, c1 and c2 in higher-plants, algae and natural phytoplankton. BPP. 1975;167:191-4

44. Wang SB, Hu Q, Sommerfeld M, Chen F. An optimized protocol for isolation of soluble proteins from microalgae for two-dimensional gel electrophoresis analysis. J Appl Phycol. 2003;15:485-96.

45. Bradford MM. Rapid and sensitive method for quantitation of microgram quantities of protein utilizing principle of protein-dye binding. Anal Biochem. 1976;72:248-54.

\section{Submit your next manuscript to BioMed Central and take full advantage of:}

- Convenient online submission

- Thorough peer review

- No space constraints or color figure charges

- Immediate publication on acceptance

- Inclusion in PubMed, CAS, Scopus and Google Scholar

- Research which is freely available for redistribution 